Saudi Journal of Business and Management Studies Abbreviated Key Title: Saudi J Bus Manag Stud ISSN 2415-6663 (Print) |ISSN 2415-6671 (Online) Scholars Middle East Publishers, Dubai, United Arab Emirates Journal homepage: http://scholarsmepub.com/sjbms/

Original Research Article

\title{
Analysis of Perceived Usefulness, Perceived Ease of Use and Service Quality on User Satisfaction in Using Snaapp Communication Application in Ignatius Slamet Riyadi Karawang Elementary School
}

\author{
Niko Faizal Akbar ${ }^{1 *}$, Dan Adi Nurmahdi ${ }^{2}$ \\ ${ }^{1}$ Student of Master Management, Universitas Mercu Buana (UMB), Jakarta Indonesia \\ ${ }^{2}$ Lecture of Master Management, Universitas Mercu Buana (UMB) Jakarta Indonesia
}

DOI: $10.36348 /$ sjbms.2019.v04i11.005

| Received: 07.09.2019 | Accepted: 14.09.2019 | Published: 28.11.2019

*Corresponding author: Niko Faizal Akbar

\section{Abstract}

This study aims to find out about: 1) the impact of perceived usefulness on user satisfaction, 2) the impact of perceived ease of use on user satisfaction, 3) the impact of service quality on user satisfaction, 4) the impact of perceived ease of use on perceived usefulness, 5) the impact of perceived usefulness and perceived ease of use on user satisfaction simultaneously. This is a quantitative research with parents from Ignatius Slamet Riyadi Karawang Elementary School as the population. The population of 300 people is narrowed down to 171 people as a sample using Quota Sampling and the Slovin formula. The data analysis with multiple linear regression shows that: 1) perceived usefulness has a positive and significant impact on user satisfaction, 2) perceived ease of use has a positive and significant impact on user satisfaction, 3) service quality has a positive and significant impact on user satisfaction, 4) perceive ease of use has a positive and significant impact on perceived usefulness, 5) perceived usefulness and perceived ease of use have a positive and significant impact on user satisfaction simultaneously.

Keywords: Perceived Usefulness, Perceived Ease of Use, Service Quality and User Satisfaction.

Copyright @ 2019: This is an open-access article distributed under the terms of the Creative Commons Attribution license which permits unrestricted use, distribution, and reproduction in any medium for non-commercial use (NonCommercial, or CC-BY-NC) provided the original author and source are credited.

\section{INTRODUCTION}

Today's technology has experienced a very rapid development. Several IT companies have sprung up. Many startups come along with the times and the needs of consumers. It was stated by Davis [1] who explained that the development of these construct items was focused on two theoretical constructs, namely the perceived usefulness and perceived ease of use which are theoretically the basic determinants of the use of the system. Quality of service is generated by the operations of the company, and the success of the company's operational processes is determined by many factors, including employees, technology systems and customer involvement.

Reflecting on a research journal conducted by
Ida Ayu and Gusti Ayu [2] entitled; "The impact of perceived usefulness, perceived ease of use and quality of service on satisfaction to build loyalty on the Gojek application", it explains that all variables have an influence on user satisfaction to build customer loyalty, except for service quality variables. Meanwhile, Muslim Amin [3] conducted a study entitled; "User satisfaction with mobile websites" also uses the same variable and it is mentioned that there is a simultaneous effect between perceived ease of use and perceived usefulness on user satisfaction. Sourced from Google Playstore 2018, it is mentioned that the rating of the Snaapp application is only 2.5 out of 5 stars. From these results, it can be said that there is a lack of satisfaction experienced by users. This app got 2.5 out of 5 stars rating from around 882 people. This certainly 
becomes a problem that can be investigated.

\section{Research Objectives}

The objectives of this study are as follows

- To analyze the impact of perceived usefulness on parents of Ign Slamet Riyadi Elementary School, Karawang's satisfaction in using Snaapp app

- To analyze the impact of perceived ease of use on parents of Ign Slamet Riyadi Elementary School, Karawang's satisfaction in using Snaapp app

- To analyze the impact of service quality on parents of Ign Slamet Riyadi Elementary School, Karawang's satisfaction in using Snaapp app

- To analyze the impact of perceived ease of use on perceived usefulness from parents of Ign Slamet Riyadi Elementary School, Karawang who use Snaapp app

- To analyze the impact of perceived ease and perceived usefulness simultaneously on parents satisfaction at Ign Slamet Riyadi Elementary School, Karawang who use Snaapp app

\section{THEORITICAL REVIEW Perceived Usefulness}

According Jogiyanto [4], perceived usefulness is defined as the extent to which someone believes that using a technology will improve work performance. While the definition of perceived usefulness, according to Davis [1], is the point where someone believes that the use of a particular system will be able to increase work performance. From the definition above, it can be concluded that the perceived usability is a user's trust in using a particular communication application to carry out their work. If the user feels that the information system is useful, he will use it. Conversely, if the user does not believe that the information system is useful, he will not use it. Thompson [5] states that individuals will use information technology if they know the positive benefits of its use. In other words, the use of technology will improve work performance and achievement of people who use it. There are 6 indicators to measure perceived usefulness according to Davis [1], namely that work gets done faster (work more quickly), makes work easier (makes job easier), improves performance (job performance), increases productivity (increase productivity).

\section{Perceived ease of use}

According to Jogiyanto [4], perceived ease of use is defined as the extent to which a person believes that using a technology will be free from effort. Davis [6] defines that perceived ease of use as a level where someone believes that using information technology can reduce one's efforts in doing something. From the definition above it can be said that perceived ease of use is a belief (believe) which someone feels that a system which he uses can be easily used, thus he will use it. And conversely, if he feels that a system is difficult to use, then he will not use the information system. Venkatesh and Davis [7] divide the dimensions of perceived ease of use as follows

- Easy to operate the system in accordance with what individuals want to do

- User interaction with information technology is clear and easy to understand

- It doesn't take much effort to interact with the system

- $\quad$ Easy-to-use system.

\section{Service Quality}

In the model SERVQUAL, service quality is defined as a global assessment or attitude regarding the superiority of a service [8], while the definition of service quality is often referred to as service value [9] is how far the difference between reality and customer expectations for the service they receive or get.

Then Parasuraman et al. in Zeithaml and Bitner [10], perfecting the dimensions so that they become 5 dimensions, namely: (i) Physical evidence (tangibles); include physical facilities, equipment, employees, and communication facilities; (ii) Reliability(reliability);namely the ability to provide the promised service immediately, accurately, and satisfactorily; (iii)Responsiveness; namely the desire of staff to help customers and provide services responsively; (iv)assurance; includes the knowledge, abilities, politeness, and trustworthiness of staff, free from danger, risk or doubt; (v) Empathy (empathy); includes ease of relationships, good communication, personal attention, and understanding the needs of customers.

\section{User Satisfaction}

Information system user satisfaction in this study is the level of user satisfaction with the application used and the output produced by the application. Stacie et al. [11] state that user satisfaction is the level of user satisfaction on reports, web sites, and support services. DeLone \& McLean [12] said that user satisfaction is the level of satisfaction of users of sites and services. Information system user satisfaction is used to measure the level of user contentment with the system and output produced. According to Gable et al. [13], the size of user satisfaction is divided into three dimensions, namely: (i) Comfort (Enjoyment). An important part of user satisfaction. Without a sense of comfort and security, the user will not feel compelled to use the application. (ii) Information Satisfaction. The ease of getting information is certainly a reason for users to use the application. (iii) System Satisfaction. An accurate system has become mandatory for application makers to facilitate its users. If the system is good, it will easily get users.

\section{Development of Hypotheses}

Based on the review of theories that have been gathered previously, the research hypothesis is proposed as follows

- H1: perceived usefulness has positive and 
significant impact on user satisfaction

- H2: perceived ease of use has a positive and significant impact on user satisfaction

- H3: service quality has a positive and significant impact on satisfaction

- H4 perceived ease of use has a positive and significant impact on perceived usefulness

- H5: perceived usefulness and perceived ease of use simultaneously have a positive impact on user satisfaction.

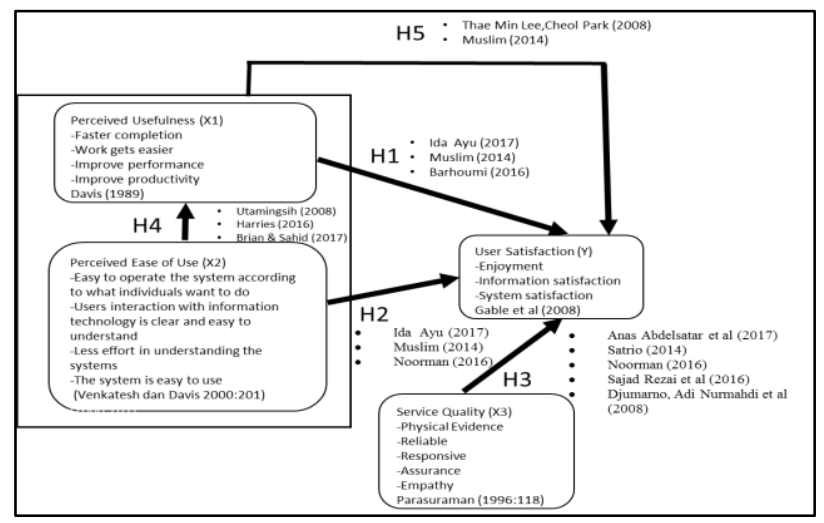

Fig-1: Research Framework

\section{RESEARCH METHODS}

Based on research background, problem identification, and the variables studied, the research design is a survey research. Survey research is generally conducted to take generalizations from indepth observations [14]. The population of this study was parents who use Snaapp app which are 300 people. The number of sample was taken using the Slovin formula with a tolerance limit of 5\% which then 171 people as sample was obtained. The sample was selected by means of non-probability sampling in which each individual was taken from the population and deliberately chosen according to the objectives of the respondents who had used the application and were in the school location.

The technique used was Quota Sampling, which was sampling based only on the research needs. Each individual chosen was a customer who had used the

Application for one semester or around six months. Data collection techniques in this study used two techniques, namely direct techniques by interviewing parents who used Snaapp application users when Snaapp opened booth of help desk and distributing questionnaires to users (student's parents or guardians), namely as respondents. Indicators of each dimension was measured using Likert scale with a score of $1-5$, with the highest value being 5 which meant strongly agree and the lowest value is 1 which meant strongly disagree.

\section{RESEARCH RESULTS \\ Validity Test}

According to Sugiyono [14], the validity test is a degree of accuracy between the data that actually occurs on the object of research and data that can be reported by researchers. In the test results it can be seen that the value of $r$ count for each dimension of perceived ease of use, perceived usefulness, service quality and user satisfaction variable $>\mathrm{r}$ table value (0.15). Thus, all of these variables are declared valid.

\section{Reliability Test}

This measurement can be done using SPSS to measure reliability with the Cronbach Alpha $(\alpha)$ statistical test, a variable said to be reliable if it gives an alpha value $(\alpha)>0.60$. In the measurement conducted, each of these variables has reliability above 0.60 .

\section{Normality Test}

A reliable method in normality test is to find out the normal probability plot which compares the cumulative distribution and the normal distribution. Normality test is based on the results of data analysis using SPSS tools, so it can be seen that the data spreads around the diagonal line and follows the direction of the diagonal line, regression models meet the assumption of normality.

\section{Multicollinearity test}

Multicollinearity test is a test conducted to ascertain whether in a regression model there is intercorrelation or colinearity which occurs between independent variables. Based on the results, it can be seen that there is no multicollinearity because these variables fulfill the requirements, namely Tolerance value is above 0.10 and VIF value is below 10 .

\section{Heterocedasticity Test}

The purpose of heteroscedasticity test itself is to test whether in the regression model there is a different variation which occurs between the residuals of one observation to another observation. Glejser test method is a statistical test that illustrates more clearly about the presence of symptoms in the heteroscedasticity test. After being tested with the Glejser method, the perceived usefulness, perceived ease and quality of service shows that $\mathrm{Sig}>0.05$, so it proves that heterocedasticity does not occur.

\section{Multiple Linear Regression Test Linear}

Regression analysis can be formulated with the following formula:

$\mathrm{Y}=4.721+0.118 \mathrm{X} 1+0.070 \mathrm{X} 2-0.339 \mathrm{X} 3+\mathrm{e}$

- Regression coefficient value of the perceived usefulness variable is 0.118 which is positive; this means that if perceived usefulness gets better, the user satisfaction will increase

- Regression coefficient value of perceived ease of use variable is 0.070 which is positive; this means 
that if perceived ease of use gets better, the user satisfaction will increase

- The regression coefficient value of service quality variable is 0.339 which is positive; this means that if the quality of service gets better, user satisfaction will increase.

\section{Linear Regression Test}

$\mathrm{X} 1=27.970+0.179 \mathrm{X} 2+\mathrm{e}$

The regression coefficient value of perceived ease of use variable is 0.179 which is positive; this means that if perceived ease of use gets better, the perceived usefulness will increase.

\section{Simultaneous Significance Test F (Test F)}

The results obtained in the $\mathrm{F}$ test are that the significance value of $0.00<0.05$ thus proving that the two variables namely the perception of benefits and perceived ease simultaneously or simultaneously have a positive effect on user satisfaction. So H5 is supported.

\section{Partial Test (T Test)}

From the table above, the perceived usefulness variable $\mathrm{t}$ value is 2.228 while the significance for the $t$ test $<0.05$ which indicates that the variable perceived usefulness partially influences user satisfaction, so $\mathrm{H} 1$ is supported. Then, for the second variable namely perceived ease of use has a $t$ value of 3.193 while the significance $<0.05$ which can be interpreted that the perceived ease of variables partially influences user satisfaction, which means $\mathrm{H} 2$ is supported. For the next variable namely service quality has a t count of 11,657 for the significance $<0.05$ which means that the service quality variable partially influences user satisfaction, so that $\mathrm{H} 3$ is supported.

\section{The coefficient of determination (R2)}

According to the table of coefficients of determination $\left(\mathrm{R}^{2)}\right.$ above, it can be explained that the values shown in $\mathrm{R}$ Square is 0.724 or $72.4 \%$. With that much percentage, it can be said that it is sufficient to represent the factors of user satisfaction. Besides, these factors have small impacts on user satisfaction.

\section{Correlation Analysis of Dimensions}

From the table of the coefficient of determination of correlation between dimensions above, it appears that the dimensions of customer satisfaction are most influenced by the dimensions of service quality variables. An authentic proof is seen where the guarantee and responsiveness dimensions have the greatest influence, namely 0.842 or $84 \%$ and 0.799 or $79 \%$.

\section{DISCUSSION}

\section{Hypothesis 1 (The impact of perceived usefulness on user satisfaction)}

Through the results of the regression assisted by SPSS, it is seen that the regression coefficient value of perceived usefulness variable is 0.118 positive which means that if the perception of benefits is getting better the user satisfaction will increase. this means that when the application used by users has great benefits, of course the satisfaction felt by the users will also increase, and vice versa. So there is a direct relationship between the benefits of the application with satisfaction.

Then through the $\mathrm{t}$ test, it is shown that the significance of the perceived usefulness to satisfaction is 0.024 and for the $t$ test $<0.05$ which indicate that the variable perceived usefulness partially affect user satisfaction, so that $\mathrm{H} 1$ is supported. This is in line with several previous studies conducted by Ida Ayu [2] and Muslim Amin [3] which results perceived the benefits significantly influence user satisfaction.

As a company engaged in application field, it is appropriate to continue to develop value-added platforms. In this case, it is certainly something that is beneficial for the users of the application (student parents or guardians). Features that help the teaching and learning process can be added in such a way that the parents or guardians of students feel in need of the app and are satisfied. It is hoped that this research can be an input for Snaapp to continue to develop new features that can also help the school in carrying out educational activities. For example, the parties could add features that can help the school to report Dapodik or Bos that usually must be reported by the school to the local education department. This system will be very much needed given the number of schools that are very difficult in recapitulating these reports.

\section{Hypothesis 2 (The impact of perceived ease of user satisfaction)}

Through the regression table above shows that the regression coefficient value of perceived ease of use variable is 0.070 positive, which means that if the perceived ease of use is better, the user satisfaction will increase. That is also supported by the results of the $t$ test which results are 0.002 which means that it is significant because $<0.05$. That means the impact of perceived ease of use significantly affects the level of user satisfaction.

Similar results also occur in research by Tao Zhou [15] on how successful an acceptance of application technology. This is no longer a secret considering the easier use of a technology or in this case the application will be even more satisfying for its users. Factors that determine the ease or smooth use are the presence or absence of bugs, whether the language in the application is easy to understand, and features 
Niko Faizal Akbar \& Dan Adi Nurmahdi; Saudi J Bus Manag Stud, Nov 2019; 4(11): 849-855

that are not too complicated. Unfortunately, at the time of observation, there were still many parents or guardians of students who found it difficult to use the Snaapp application. This is a job that needs to be addressed by the company. Language that is still mixed between English and Indonesian is a separate issue that must be addressed.

\section{Hypothesis 3 (The impact of service quality on user satisfaction)}

From the regression table above, it shows that the next variable that is service quality has a t count of 11,657 for the significance $<0.05$ which means that service quality significantly influences user satisfaction. This research means that it is not in line with Ida Ayu [2] who said that service quality has no significant effect on user satisfaction but this evidence is in line with research from Anas Abdelsatar et al. [16] stating that service quality was found to be a strong predictor of customer satisfaction. Previous research has corroborated the results of this study $[11,17,18$, 19]. Therefore, the results show that the level of customer satisfaction will increase when the quality of service increases. In accordance with that, in the correlation of dimensions table above, the quality of service is the variable with the most influence on the dimensions of user satisfaction compared to other variables.

Quality of service becomes very vital in relation to user satisfaction considering that in this study the effect was most dominant compared to the others. Apart from the shortcomings in terms of perceived usefulness and convenience, good and maximum quality of service is enough to reduce the user's dissatisfaction. That indicates the need for intense monitoring and service activities so that all forms of complaints regarding the application can be handled properly.

\section{Hypothesis 4 (The impact of perceived ease of use on perceived usefulness)}

The regression coefficient value of the perception of use variable is $0.179 \mathrm{X} 2$ positive which means that if the perceived ease of use gets better, the perceived usefulness will increase. In addition, the $t$ test in the table above also shows the value of perceived usefulness variable $t$ is 6.095 while the significance for the $t$ test $<0.05$ which indicates that the perceived usefulness variable partially influences the perceived ease of use, so that $\mathrm{H} 4$ is supported. This has the same result as the study conducted by Theo et al. [20] and Harries Arizonia [21] who assumes that perceived ease of use has a positive and significant impact on the perceived usefulness.

Logically, of course, if a user can already use an application, he certainly can feel the benefits. With this analogy, Snaapp must continue to update the system to make it easier for users to operate the application. Without the ease of accessing applications, users will certainly not be able to feel the benefits.

\section{Hypothesis 5 (The impact of perceived usefulness and perceived convenience on user satisfaction simultaneously)}

From the data above, it can be seen that the significance value $<0.05$ thus proving that the two variables namely perceived usefulness and perceived ease of use simultaneously have positive impact on user satisfaction. This is also supported by research from Thae Min Lee, Cheol Park [18] and research from Muslim Amin [3].

Both of these variables, namely the perceived usefulness and perceived ease of use are the variables that play a role in research in the field of technology and are part of the TAM (Technology Acceptance Model).Thus, the relationship of both variables cannot be denied, especially for the satisfaction of application users. The company certainly must not forget these two variables if you want to continue to satisfy users.

\section{CONCLUSION}

Technology has experienced a very rapid development. Several IT companies have sprung up. Many startups come along with the times and the needs of consumers to find convenience in accessing all information and meeting their daily needs. So far, there have been various types of startups that invaded Indonesia. From online transportation to online shopping has mushroomed among the people of Indonesia. Gadgets users are greatly facilitated by the presence of applications on devices. Customers of startup application are already diverse. From young people to parents, they are given "shortcuts" in carrying out various activities. Applications or startups in the world of education have also mushroomed, given the large number of schools in Indonesia. Many schools already use these applications which function is certainly to facilitate schools in achieving effectiveness and efficiency. One application that has these objectives is Snaapp (School Notification and Attendance Application). Snaapp is an application that has been running in almost all schools in Singapore and began to be tested by several schools in Indonesia. As an application, Snaapp must continue to develop its applications. In a pre-survey aimed at parents, many criticisms are thrown at this application. Many of the parents or guardians of students find it difficult to operate this application, in terms of language that is still "mixed" between English and Indonesian, problems when logging in and so on. Besides, from previous studies, it was found that the TAM (Technology Acceptance Model) factors had a significant influence on user satisfaction besides service quality variables. 
Niko Faizal Akbar \& Dan Adi Nurmahdi; Saudi J Bus Manag Stud, Nov 2019; 4(11): 849-855

\section{SUGGESTION}

In this study there is an interesting fact. It is actually the quality of service that plays the biggest role in influencing user satisfaction. Through this research, we know that even though there are negative statements from users, in terms of perceived usefulness and perceived convenience, it can still be covered if the company has good service quality. Because it can be seen that many users expect service if there are problems with bugs and so on, then from this study the authors provide advice for companies, namely:

1) For marketing or customer service, they are expected to be quick in serving complaints from users. In the aspect of guarantee and responsiveness whose indicators include: Behavior of employees to convince users, speed in serving users, and employees who are always willing to help, interpreting the need for a monitoring usage that is quite intense in schools or by creating a help desk periodically.

2) Maybe basically the users already know and understand if there are still deficiencies in the features that exist in the application, but there must be reciprocity from the company that is with good service and system development to be even better. As a company engaged in the application field, it is appropriate to continue to develop value-added platforms. In this case, it is certainly something that is beneficial for the users of the application (student guardians). Features that help the teaching and learning process can be added in such a way that the guardians of students feel in need of the app and are satisfied. It is hoped that this research can be an input for Snaapp to continue to develop new features that can also help the school in carrying out educational activities. For example Snaapp can add features that can help schools do Dapodik or Bos reporting which usually must be reported by schools to local education offices. This system will be very much needed given the number of schools that are very difficult in recapitulating these reports. This is no longer a secret considering the easier use of a technology or in this case the application will be even more satisfying for its users. 3) Then the factors that determine the ease or smoothness of use, such as the presence or absence of bugs, whether the language in the application is easy to understand, and features that are not too complicated. Unfortunately, at the time of observation, there were still many parents or guardians of students who found it difficult to use the Snaapp application. This is an issue that needs to be addressed by the company. Language that is still mixed between English and Indonesian is a separate issue that must be addressed. Then of course, we know that service quality becomes very vital in relation to user satisfaction considering that in this study the effect was most dominant compared to the others. Apart from the shortcomings in terms of perceived usefulness and convenience, good and maximum quality of service is enough to reduce the user's dissatisfaction. This indicates the need for intense monitoring and service activities so that all forms of complaints regarding the application can be handled properly. Logically, of course, if a user can already use an application, he certainly can feel the benefits. With this analogy, Snaapp must continue to update the system to make it easier for users to operate the application.

\section{REFERENCE}

1. Davis, F. D. (1989). Perceived usefulness, perceived ease of use, and user acceptance of information technology. MIS quarterly, 319-340.

2. Mandasari, I. A. C., \& Giantari, I. G. A. K. (2017). Pengaruh Perceived Usefulness, Perceived Ease Of Use, Dan Kualitas Layanan Terhadap Kepuasan Untuk Membangun Loyalitas. E-Jurnal Ekonomi dan Bisnis Universitas Udayana, 6, 3637-3664.

3. Amin, M., Rezaei, S., \& Abolghasemi, M. (2014). User satisfaction with mobile websites: the impact of perceived usefulness (PU), perceived ease of use (PEOU) and trust. Nankai Business Review International, 5(3), 258-274.

4. Jogiyanto, H. M. (2007). Sistem informasi keperilakuan. Yogyakarta: Andi Offset.

5. Thompson, A. (2007). In fantasy land, sports judges hear imaginary cases. The Wall Street Journal, A1.

6. Davis, F. D. (1985). A technology acceptance model for empirically testing new end-user information systems: Theory and results (Doctoral dissertation, Massachusetts Institute of Technology).

7. Venkatesh, V. \& Davis, F. (2000). A theoretical extension of the technology acceptance model : four longitudinal field studies. Management Science 46(2), 186-204.

8. Parasuraman, A., Zeithaml, V. A., \& Berry, L. L. (1985). A conceptual model of service quality and its implications for future research. The Journal of Marketing, 41-50.

9. Berry, L. L. (1988). SERVQUAL: A multiple-item scale for measuring consumer perceptions of service quality. Journal of retailing, 64(1), 12-40.

10. Zeithaml, V. A., Bitner, M. J., \& Dremler, D. (1996). Services Marketing, international edition. New York, NY and London: McGraw Hill.

11. Petter, S., DeLone, W., \& McLean, E. (2008). Measuring information systems success: models, dimensions, measures, and interrelationships. European journal of information systems, 17(3), 236-263.

12. Delone, W. H., \& McLean, E. R. (2003). The DeLone and McLean model of information systems success: a ten-year update. Journal of management information systems, 19(4), 9-30.

13. Gable, G. G., Sedera, D., \& Chan, T. (2008). Reconceptualizing information system success: The IS-impact measurement model. Journal of the association for information systems, 9(7), 18. 
14. Sugiyono. (2007). Metode Penelitian Pendidikan, Pendekatan Kuantitatif, Kualitatif dan R\&D. Bandung: Alphabeta..

15. Zhou, T. (2011). Examining the critical success factors of mobile website adoption. Online Information Review, 35(4), 636-652.

16. Mohammad Salameh, A. A., Ahmad, H., Zulhumadi, F., \& Abubakar, F. M. (2018). Relationships between system quality, service quality, and customer satisfaction: M-commerce in the Jordanian context. Journal of Systems and Information Technology, 20(1), 73-102.

17. Cronin Jr, J. J., \& Taylor, S. A. (1992). Measuring service quality: a reexamination and extension. Journal of marketing, 56(3), 55-68.

18. Lee, T. M., \& Park, C. (2008). Mobile technology usage and B2B market performance under mandatory adoption. Industrial Marketing Management, 37(7), 833-840.

19. Udo, G. J., Bagchi, K. K., \& Kirs, P. J. (2010). An assessment of customers'e-service quality perception, satisfaction and intention. International Journal of Information Management, 30(6), 481492.

20. Teo, G., Vogel, C., Ghosh, D., Kim, S., \& Choi, H. (2013). PECA: a novel statistical tool for deconvoluting time-dependent gene expression regulation. Journal of proteome research, 13(1), 29-37.

21. Ismail, H. A. (2016). Intention to Use Smartphone through Perceived Compatibility, Perceived Usefulness, and Perceived Ease of Use. Jurnal Dinamika Manajemen, 7(1), 1-10. 